\title{
THE POTENCY OF LUBUK LARANGAN JORONG IKAN BANYAK AS LOCAL WISDOM BASED ECOTOURISM AREA
}

\section{POTENSI LUBUK LARANGAN JORONG IKAN BANYAK SEBAGAI KAWASAN EKOWISATA BERBASIS KEARIFAN LOKAL}

\author{
Fiona Novianti ${ }^{1}$, Muhammad Fauzi ${ }^{1}$, Adriman ${ }^{1}$ \\ ${ }^{1}$ Manajemen Sumberdaya Perairan Fakultas Perikanan dan Kelautan Universitas Riau, Jl. HR Soebrantas Km \\ 12,5 Simpang Baru, Panam - Pekanbaru, Indonesia 28293 \\ Correspondence Author : fionanovianti191@gmail.com
}

\begin{tabular}{l}
\hline I N F O A R T I K E L \\
\hline Submited : 10 Desember 2018 \\
Revised : 5 Januari 2019 \\
Approved : 14 Januari 2019 \\
\hline
\end{tabular}

Keywords:

conservation area, ecological tourism, Tor tambroides, Lima Puluh Kota

\begin{abstract}
A B S T R A C T
This study aims to understand the local wisdom and the feasibility of the area as an ecological tourism object has been carried out from February to March 2018. The method used in this study is the survey method. Water quality data collection was carried out four times (once/two weeks), while questionnaires were distributed prior to environmental data collection. Water samples were taken from three stations, while local wisdom data were collected through questionnaires. Results shown that the community used to maintain the Jorong Ikan Banyak ecosystem by applying regulations for fish capture. Water quality parameter values of the Lubuk Larangan are as follows : temperature was 22.5-230c; water depth was 71.75-120.25 cm; current speed was $0.25-0.42 \mathrm{~m} / \mathrm{s}$; dissolved oxygen was $4.6-4.8 \mathrm{mg} / \mathrm{l}$ and $\mathrm{pH}$ was 6 . The tourism potential element scores of the Lubuk Larangan were as follows: Attractiveness 1,095; Accessibility 537.5; Accommodations 45 and Facilities 240, total score 1,917.5. This score indicates that the Lubuk Larangan Jorong Ikan Banyak is suitable for tourism object.
\end{abstract}

\section{PENDAHULUAN}

Provinsi Sumatera Barat merupakan daerah yang banyak terdapat kawasan konservasi (suaka perikanan) yang dikelola oleh masyarakat lokal dan lebih dikenal dengan istilah lubuk larangan. Keberadaan lubuk larangan sebagai salah satu wujud upaya konservasi sumberdaya perikanan di wilayah Sumatera Barat memiliki peranan penting bagi masyarakat (Firdaus dan Yesi, 2010).

Menurut Oktaviani et al., (2016), pada tahun 2009 terdapat 734 lubuk larangan yang tersebar di 18 Kabupaten diantaranya yaitu Lima Puluh Kota, Dharmasraya, Agam dan Pasaman. Salah satu lubuk larangan yang ada di Kabupaten Lima Puluh Kota yaitu terdapat di Jorong Ikan Banyak Nagari Pandam Gadang. Pengelolaan lubuk larangan yang diterapkan oleh masyarakat Jorong Ikan Banyak merupakan sebuah kearifan lokal masyarakat yang partisipatif, adaptif dan berkelanjutan.

Dengan sistem pengelolaan yang telah dilaksanakan, kawasan tersebut dapat dijadikan sebagai objek ekowisata, sehingga dapat memberikan dampak positif secara ekologi, sosial budaya dan ekonomi. Saat ini, kegiatan wisata pada kawasan sudah mulai dilakukan. Namun, destinasi wisata ini belum dikelola dengan baik, dikhawatirkan dapat menyebabkan kemunduran dan kerusakan kawasan lubuk larangan tersebut. Selain itu, karakteristik fisika-kimia di kawasan lubuk larangan juga harus diperhatikan, agar ikan yang ada pada Lubuk Larangan Jorong Ikan Banyak dapat hidup dengan baik. Untuk mempertahankan kegiatan konservasi dan meningkatkan perekonomian masyarakat di kawasan 
ini, maka perlu dilakukan penelitian mengenai Potensi Lubuk Larangan Jorong Ikan Banyak Sebagai Kawasan Ekowisata Berbasis Kearifan Lokal.

\section{METODE PENELITIAN}

\section{Watu dan Tempat}

Penelitian ini dilaksanakan pada bulan Februari - Maret 2018 di Kawasan Lubuk Larangan Jorong Ikan Banyak Nagari Pandam Gadang Kabupaten Lima Puluh Kota. Pengamatan parameter fisika-kimia dilakukan pada tiga titik stasiun pengamatan antara lain :

1. Bagian hulu : 50 meter bagian hulu sebelum lubuk larangan.

2. Lubuk larangan : lokasi lubuk larangan.

3. Bagian hilir : 50 meter kebagian hilir setelah lubuk larangan.

Pengambilan sampel dilakukan sebanyak empat kali dengan interval waktu pengambilan sampel dua kali selama 1 bulan. Parameter yang diukur meliputi: suhu, kecepatan arus, kedalaman perairan, oksigen terlarut (DO) dan Derajat Keasaman (pH).

\section{Alat dan Bahan}

Alat yang digunakan dalam penelitian ini adalah alat tulis, kamera handphone dan peralatan yang digunakan untuk mengukur parameter fisika-kimia berupa thermometer, tali ravia, botol mineral, stopwatch, meteran, botol BOD $125 \mathrm{ml}$, erlemeyer, pipet tetes, jarum suntik dan indikator $\mathrm{pH}$. Sedangkan bahan yang digunakan dalam penelitian ini adalah $\mathrm{MnSo}_{4}, \mathrm{NaOH}-\mathrm{KI}, \mathrm{H}_{2} \mathrm{SO}_{4}$. $\mathrm{Na}_{2} \mathrm{~S}_{2} \mathrm{O}_{3} 5 \mathrm{H}_{2} \mathrm{O}$ dan Amilum serta kuisioner yang dibagikan kepada responden di lokasi penelitian.

\section{Metode yang Digunakan}

Metode yang digunakan dalam penelitian ini adalah metode survey. Jumlah responden yang dipilih sebanyak 69 orang yang terdiri dari Pemerintahan Nagari Pandam Gadang sebanyak 2 orang, Tokoh Adat sebanyak 2 orang, Pengunjung sebanyak 55 orang dan Masyarakat sekitar sebanyak 10 orang.

Pengumpulan data tentang kearifan lokal lubuk larangan dilakukan dengan wawancara terpandu kepada pihak-pihak yang mengetahui secara pasti tentang objek yang diteliti.

Data potensi objek ekowisata lubuk larangan terdiri dari penilaian daya tarik, aksesibilitas, akomodasi, sarana dan prasarana penunjang.

Data mengenai potensi ekowisata lubuk larangan Jorong Ikan Banyak diolah dengan menggunakan Pedoman Analisis Daerah Operasi Obyek dan Daya Tarik Wisata Alam (ADOODTWA) Direktorat Jenderal PHKA (2003a) yang telah dimodifikasi sesuai dengan nilai/skor yang telah ditentukan untuk masing-masing kriteria (Tabel 1). Jumlah nilai untuk satu kriteria penilaian ODTWA dapat dihitung dengan persamaan sebagai berikut:

$\mathbf{S}=\mathbf{N} \times \mathbf{B}$

Keterangan : $\mathrm{S}=$ skor/nilai suatu kriteria

$\mathrm{N}=$ nilai unsur-unsur pada kriteria

$\mathrm{B}=$ bobot nilai

Untuk analisis strategi pengembangan kawasan Lubuk Larangan Jorong Ikan Banyak menggunakan analisis SWOT.

\section{HASIL DAN PEMBAHASAN}

\section{Kearifan Lokal}

HB. Dt. Majo Lobiah (tokoh adat) menyatakan bahwa lubuk larangan Jorong Ikan Banyak Nagari Pandam Gadang ada di Batang Sinamar sejak Tahun 1822. Pada Tahun 1912 lubuk larangan sudah mulai dipertahankan keberadaannya. Pada Tahun 1942 ketika Jepang masuk ke Indonesia kegiatan pelestarian ini dihancurkan/ dimusnahkan. Pada Tahun 1951, ikan larangan yang ada dalam lubuk larangan telah berkembang biak secara alami. Selanjutnya pada Tahun 1959, kegiatan pelestarian kembali dilaksanakan.

Namun, pelaksanaannya kembali mengalami gangguan karena adanya perang saudara di Sumatra Barat. Pada Tahun 1960, kawasan lubuk larangan ini kembali dikelola langsung oleh Nagari di bawah bimbingan Dinas Perikanan Kabupaten Lima Puluh Kota. Pada saat itu, juga dilakukan 
penebaran benih ikan (Restocking) yang terdiri dari benih ikan tawas, ikan nila dan ikan mas. Namun, ikan yang mampu bertahan dan berkembang dengan baik dilokasi lubuk larangan ini hanyalah ikan Garing. Pada pembentukan kembali kawasan lubuk larangan ini ditetapkanlah aturan-aturan dan sanksi-sanksi dalam bentuk adat. Kegiatan pelestarian lubuk larangan ini masih terus berlanjut hingga sekarang dan telah difasilitasi oleh Dinas Perikanan Kabupaten Lima Puluh Kota dan Dinas terkait.

\section{Tata Cara Pembentukan Lubuk Larangan}

Tahap 1:

Pembentukan lubuk larangan Jorong Ikan Banyak dimulai dengan adanya ide/ gagasan yang disampaikan oleh seorang pemuka agama yang bernama H. Sholeh. Setelah menyampaikan idenya tersebut, maka dilakukanlah musyawarah.

Tahap 2:

Musyawarah dilakukan di masjid setelah sholat jum'at dengan dihadiri oleh pemerintah Nagari, pemuka adat, pemuka agama, tokoh masyarakat, pemuda dan masyarakat untuk menentukan syarat, waktu dan batas-batas lubuk larangan. Syarat yang digunakan dalam membentuk lubuk larangan di Jorong Ikan Banyak yaitu berupa jenis bunga-bungaan dan tanaman-tanaman obat yang diyakini pada masa itu. Batas-batas kawasan lubuk larangan yang telah ditentukan yaitu 50 meter ke hulu dan 50 meter ke hilir dari kawasan lubuk larangan tersebut.

Tahap 3:

Pembukaan lubuk larangan dilakukan secara adat yaitu dengan berdoa secara bersama-sama di lubuk larangan yang dipimpin oleh $\mathrm{H}$. Sholeh. Setelah berdoa maka syarat-syarat yang telah dikumpulkan sebelumnya di tebarkan pada kawasan lubuk larangan. Kemudian disampaikanlah istilah "uduah" yang berisi bahwa ikan yang ada pada kawasan ini tidak boleh di tangkap, di rusak dan dimusnahkan. Masyarakat yang melanggar aturan lubuk larangan akan mendapatkan "mudarat" yaitu sanksi berupa denda (uang dan barang) dan juga sanksi mistik yaitu menimbulkan sakit perut, bengkak-bengkak, jiwa yang tidak tenang dan lain sebagainya.

Menurut Lubis (2005), pengunduhan dinilai efektif dalam pelaksanaan lubuk larangan. Pengunduhan ini membuktikan bahwa kearifan lokal dalam pengelolaan sumber daya memang umumnya dikemas dalam terminologi pantangan yang menunjukkan corak religius-magis dan larangan yang berbentuk aturan hukum adat, yang meskipun memiliki landasan yang berbeda namun keduanya memberi efek positif bagi konservasi sumber daya alam.

\section{Pengelolaan Lubuk Larangan}

\section{a. Adanya POKMASWAS (Kelompok Masyarakat Pengawas)}

Pengelolaan lubuk larangan Jorong Ikan Banyak diserahkan kepada POKMASWAS (Kelompok Masyarakat Pengawas). Adapun tugas dari POKMASWAS Jorong Ikan Banyak yaitu:

1. Melestarikan dan mengembangkan ikan-ikan yang ada pada lubuk larangan.

2. Mengawasi masyarakat yang melakukan kegiatan yang merugikan dan membahayakan pada ikan yang ada di lubuk larangan.

3. Sanitasi/ pembersihan lingkungan.

\section{b. Peraturan dan Sanksi}

Selain adanya POKMASWAS yang mengelola kawasan lubuk larangan, masih terdapat aturan dan sanksi adat. Sanksi adat ini terbentuk karena adanya "uduah" yang memagari kawasan lubuk larangan tersebut. Aturan yang ada di kawasan lubuk larangan Jorong Ikan Banyak yaitu:

a. Larangan mengambil ikan yang berada pada lubuk larangan

b. Larangan mengganggu ikan dan merusak kawasan lubuk larangan

c. Larangan untuk berbicara dan berprilaku tidak baik di kawasan lubuk larangan

Aturan-aturan tersebut telah dipatuhi oleh masyarakat sejak awal terbentuknya kawasan lubuk larangan Jorong Ikan Banyak. Aturan tersebut tertulis dalam Peraturan Nagari Nomor 434 Tahun 2014 tentang Pengelolaan Lubuk Larangan dan juga berupa aturan lisan yang disampaikan dari mulut ke mulut secara turun temurun namun telah dipahami dan dipatuhi oleh masyarakat hingga sekarang. Hal yang boleh dilakukan di lubuk larangan adalah memberi makan ikan, bermain air, mandi dan mencuci. Pelanggaran terhadap aturan lubuk larangan dapat menimbulkan sakit perut, bengkak-bengkak dan jiwa yang tidak tenang. 


\section{Manfaat Lubuk Larangan Jorong Ikan Banyak}

Keberadaan lubuk larangan Jorong Ikan Banyak memiliki manfaat baik dari segi ekologi, ekonomi dan siosial. Manfaat tersebut adalah:

a. Secara ekologi: keberadaan lubuk larangan merupakan salah satu upaya pelestarian ikan Garing yang telah susah ditemukan di tempat lain. Selain itu, keberadaan lubuk larangan Jorong Ikan Banyak juga dapat mencegah terjadinya kerusakan yang disebabkan oleh aktivitas-aktivitas masyarakat.

b. Secara ekonomi: keberadaan lubuk larangan Jorong Ikan Banyak dapat menjadi tempat untuk memperoleh penghasilan yaitu dengan berdagang berbagai makanan dan minuman serta pelet untuk dijadikan makan ikan. selain itu, juga dapat menambah pemasukan khas desa atau pemuda.

c. Secara sosial: keberadaan lubuk larangan dapat menumbuhkan tali silaturrahmi meningkatkan rasa cinta dan kepedulian terhadap sesama dan pelestarian sumberdaya hayati perikanan. Selain itu, juga terbinanya kerukunan dan rasa kesetiakawanan di lingkungan masyarakat dan dijadikan tradisi adat.

\section{Zonasi dan Karakteristik Kualitas Air Lubuk Larangan \\ Zona Inti}

Zona inti adalah suatu kawasan yang digunakan untuk area pemijahan dan pengasuhan ikanikan langka untuk menjaga kelestariannya yang memiliki ekosistem yang masih alami dan mempunyai kondisi perairan yang masih asli atau belum diganggu manusia. Pada penelitian ini yang menjadi zona inti adalah kawasan lubuk larangan Jorong Ikan Banyak (Stasiun II) yang memiliki panjang $100 \mathrm{~m}$, lebar lebih kurang $10 \mathrm{~m}$ dan kedalaman lebih kurang $120 \mathrm{~cm}$. Pada kawasan ini dapat dengan jelas terlihat ikan-ikan yang bergerombol dan terdapat tumbuh-tumbuhan atau pepohonan yang rindang sehingga menghambat cahaya matahari sampai ke perairan sungai.

\section{Zona Pemanfaatan}

Zona pemanfaatan adalah area atau tempat di sekitar kawasan lindung yang dapat dimanfaatkan oleh masyarakat yang dilakukan dengan tetap memperhatikan kelestarian ekosistem setempat. Zona pemanfaatan kawasan lubuk larangan Jorong Ikan Banyak berada pada bagian hulu sebelum Lubuk Larangan dan bagian hilir setelah lubuk larangan. Pada zona pemanfaatan bagian hulu dan hilir lubuk larangan Jorong Ikan Banyak ini dapat dimanfaatkan untuk berbagai kegiatan yaitu memanfaatkan air sungai untuk keperluan pertanian, kebutuhan sehari-hari (mandi/mencuci) dan menangkap ikan dengan alat tangkap yang ramah lingkungan.

\section{Karakteristik Fisika-Kimia}

Karakteristik fisika-kimia air Sungai Batang Sinamar pada tiga Stasiun pengamatan (Tabel 2). Rata-rata suhu lubuk larangan yaitu $22,5-23^{\circ} \mathrm{C}$. Rendahnya suhu pada Stasiun II disebabkan karena perairannya relatif tertutup oleh tumbuh-tumbuhan, sehingga penetrasi cahaya matahari terhalang masuk keperairan. Sedangkan suhu tinggi pada Stasiun I dan III disebabkan karena kawasan perairannya relatif terbuka, sehingga permukaan perairan langsung terkena oleh cahaya matahari. Menurut Effendi (2003), cahaya matahari yang masuk ke perairan akan mengalami penyerapan dan perubahan menjadi energi panas sehingga mempengaruhi suhu.

Kedalaman Sungai Batang Sinamar pada Stasiun pengamatan yaitu 71,75-120,25 cm. Tingginya kedalaman perairan pada Stasiun II diduga karena pada dasarnya terdapat lekuk seperti mangkuk (lubuk) dan subtrat berlumpur sehingga lebih dalam.

Kecepatan arus pada setiap Stasiunnya dengan rata-rata $25-42 \mathrm{~cm} / \mathrm{s}$. Kecepatan arus tertinggi terdapat pada Stasiun I dikarenakan tingkat kemiringannya lebih tinggi dibandingkan dengan Stasiun lainnya dan kecepatan arus terendah terdapat pada Stasiun II dikarenakan daerah tersebut lebih datar, dalam dan lebih lebar dibandingkan dengan Stasiun lainnya. Kecepatan arus sungai Batang Sinamar pada Stasiun II tergolong arus yang lambat, sedangkan pada stasiun I dan III memiliki arus yang sedang.

Oksigen Terlarut yang diperoleh yaitu 4,6-4,8 mg/l. Tingginya oksigen terlarut pada Stasiun I dan III disebabkan karena perairan yang relatif terbuka sehingga cahaya matahari lebih banyak masuk ke perairan sehingga kandungan oksigen terlarut akan meningkat. Sedangkan pada stasiun II, rendahnya oksigen terlarut disebabkan karena perairannya relatif tertutup oleh tumbuh-tumbuhan, 
sehingga penetrasi cahaya kurang. Selain itu, stasiun II merupakan kawasan ekowisata lubuk larangan sehingga banyak terdapat aktivitas masyarakat dan pengunjung pada kawasan tersebut seperti mandi, memberi makan ikan berupa pelet dan sebagainya. Effendi (2003), menyatakan bahwa perbedaan oksigen terlarut dipengaruhi oleh kondisi dan topografi lingkungan yang mempunyai kemiringan, maka kecepatan arus kuat sehingga terjadi pengadukan (mixing) yang berpengaruh terhadap oksigen terlarut suatu perairan.

Derajat keasaman $(\mathrm{pH})$ yang didapat di sungai Batang Sinamar kawasan lubuk larangan Jorong Ikan Banyak selama penelitian adalah 6.

\section{Analisis Persepsi Pengunjung \\ Daya Tarik}

Berdasarkan penilaian daya tarik, menunjukkan $100 \%$ responden menyatakan lubuk larangan Jorong Ikan Banyak memiliki keunikan sumberdaya alam yang terdiri dari tebing, flora, fauna, kebudayaan dan sungai. Hasil penilaian kepekaan sumberdaya alam, 100\% responden juga menyatakan lubuk larangan ini sangat baik karena terdapat nilai pengetahuan, budaya/sejarah, pengobatan, kepercayaan dan adat istiadat.

Untuk banyaknya sumberdaya alam yang menonjol, sebanyak $87,27 \%$ responden menyatakan bahwa sumberdaya yang menonjol yaitu flora, fauna dan air. Ada 3,64 \% menyatakan flora dan fauna serta $9,1 \%$ menyatakan hanya fauna yang merupakan ikan pada lubuk larangan tersebut. Penilaian variasi kegiatan (Gambar 1) menunjukkan bahwa 70,9\% pengunjung menyatakan bahwa kegiatan yang bisa dilakukan di kawasan lubuk larangan Jorong Ikan Banyak adalah menikmati keindahan alam, melihat flora dan fauna, penelitian/ pendidikan dan mandi/berenang, sebanyak 23,64\% responden menyatakan menikmati keindahan alam, melihat flora dan fauna serta penelitian/ pendidikan, 5,45\% responden menyatakan menikmati keindahan alam dan melihat flora fauna yang ada di lubuk larangan.

Kondisi kebersihan lokasi 10,9\% responden menyatakan lubuk larangan ini tidak ada pengaruh dari industri, kepadatan lalu lintas, sampah, pemukiman penduduk, vandalisme (coret-coret) dan pencemaran lainnya dan 90,1\% menyatakan tidak ada pengaruh dari industri, jalan ramai, sampah dan vandalisme (coret-coret). Untuk keamanan dan kenyamanan, $100 \%$ responden menyatakan aman dan $100 \%$ responden juga menyatakan nyaman. Berdasarkan penilaian unsur daya tarik memperoleh nilai skor 1095 dari nilai maksimum 1260.

\section{Aksesibilitas}

Akses menuju lubuk larangan Jorong Ikan Banyak dapat dicapai melalui jalan darat dengan kondisi yang baik (Gambar 2). Berdasarkan data kuisioner, 100\% pengunjung menyatakan bahwa kondisi jalan baik. Untuk jarak tempuh menuju kawasan sebanyak 30,9\% pengunjung menyatakan bahwa lubuk larangan ini tidak terlalu jauh yaitu $10-15 \mathrm{~km}$ dan sebanyak $69,1 \%$ pengunjung menyatakan bahwa untuk mencapai kawasan lubuk larangan harus menempuh jarak $>15 \mathrm{~km}$.

Dari segi tipe jalan, 100\% responden menyatakan bahwa jalan menuju lubuk larangan baik dengan jalan aspal dan lebar $3 \mathrm{~m}$. Selanjutnya $100 \%$ pengunjung menyatakan bahwa waktu yang diperlukan untuk mencapai lubuk larangan adalah 1-2 jam. Berdasarkan penilaian yang telah dilakukan, maka aksesibilitas memperoleh nilai skor 537,5 dari nilai maksimum 600.

\section{Akomodasi}

Sebanyak $78 \%$ responden menyatakan bahwa terdapat 1 akomodasi yang berjarak $\pm 10 \mathrm{~km}$ dari kawasan lubuk larangan dan $22 \%$ responden menyatakan bahwa tidak terdapat akomodasi di sekitar kawasan lubuk larangan. Untuk jumlah kamar, $78 \%$ responden menyatakan bahwa terdapat <30 kamar yang tersedia dalam satu akomodasi dan sebanyak $22 \%$ responden menyatakan tidak terdapat kamar maupun akomodasi di sekitar kawasan lubuk larangan (Gambar 3).

Akomodasi berada $\pm 15 \mathrm{~km}$ dan masih dapat menunjang keberadaan kawasan wisata. Hal ini sesuai Arafah dan Alamsyah (2010), yang menyatakan bahwa unsur yang digunakan dalam menilai perhotelan/ penginapan didasarkan pada jumlah kamar hotel/ penginapan yang berada radius $15 \mathrm{~km}$ dari objek wisata.

Pada kawasan lubuk larangan Jorong Ikan Banyak keberadaan akomodasi tidak terlalu memberikan pengaruh terhadap keberlangsungan kawasan tersebut. Hal ini disebabkan karena pengunjung yang datang ke kawasan lubuk larangan ini biasanya hanya menghabiskan waktu selama 
1-3 jam dan langsung pulang ke daerahnya masing-masing. Berdasarkan penilaian tersebut, maka akomodasi memperoleh nilai skor 45 .

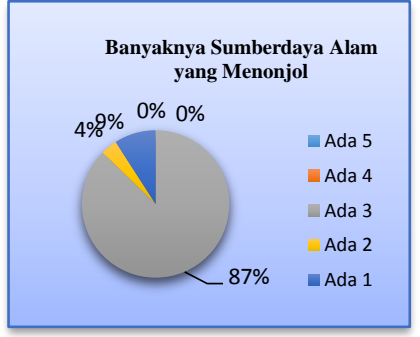

(a)

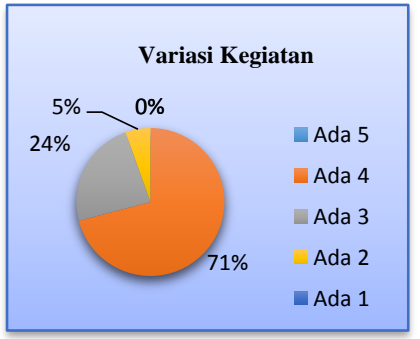

(b)

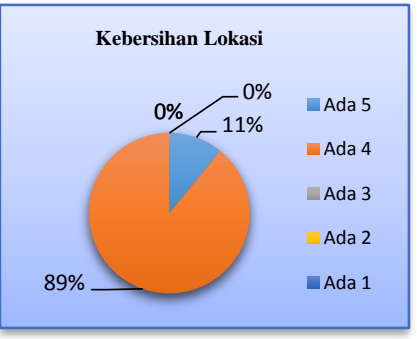

(c)

Gambar 1. Persepsi Pengunjung Terhadap (a) Banyaknya Sumberdaya Alam yang Menonjol, (b) Variasi Kegiatan dan (c) Kebersihan Lokasi Kriteria Daya Tarik.

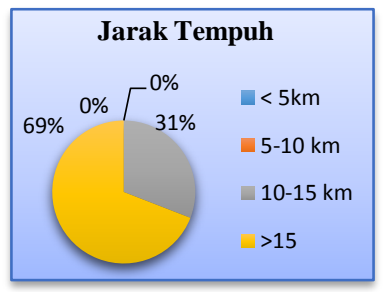

Gambar 2. Persepsi Pengunjung Terhadap Jarak Tempuh Kriteria Aksesibilitas.

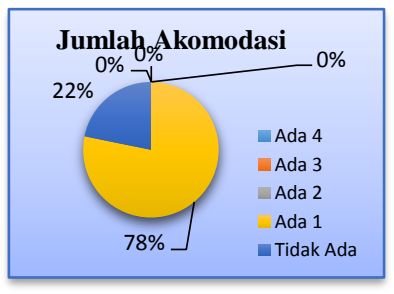

(a)

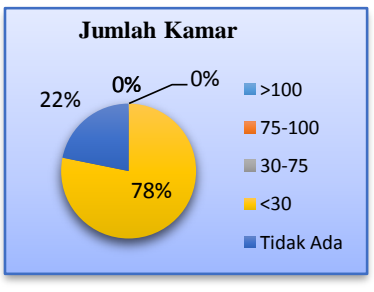

(b)

Gambar 3. Persepsi Pengunjung Terhadap (a) Jumlah Akomodasi, (b) Jumlah Kamar Kriteria Akomodasi.

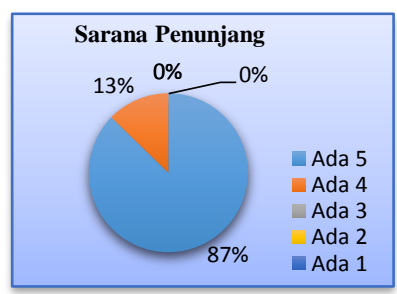

(a)

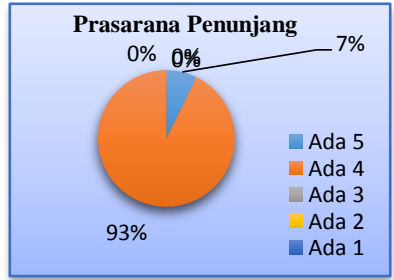

(b)

Gambar 4. Persepsi Pengunjung Terhadap (a) Sarana Penunjang, (b) Prasarana Penunjang Kritariea Sarana dan Prasarana Penunjang. 
Tabel 1. Kriteria penilaian Pedoman Analisis Daerah Operasi Obyek dan Daya Tarik Wisata Alam (ADO-ODTWA)

\begin{tabular}{|c|c|c|c|}
\hline No. & Unsur & Bobot & Skor Maks \\
\hline 1. & Daya Tarik & 6 & 1260 \\
\hline 2. & Aksesibilitas & 5 & 600 \\
\hline 3. & Akomodasi & 3 & 180 \\
\hline 4. & Sarana dan Prasarana Penunjang & 3 & 300 \\
\hline & $\begin{array}{l}\text { Skor Total: } \\
\end{array}$ & & 2340 \\
\hline
\end{tabular}

Tabel 2. Rata-Rata Pengukuran Parameter Fisika-Kimia Kawasan Lubuk Larangan Selama Penelitian

\begin{tabular}{llllll}
\hline No & Parameter & Satuan & \multicolumn{2}{l}{ Stasiun } & \\
\cline { 3 - 5 } & & I & II & III \\
\hline 1 & Suhu & ${ }^{0} \mathrm{C}$ & 23 & 22,5 & 23 \\
2 & Kedalaman Perairan & $\mathrm{Cm}$ & 71,75 & 120,25 & 105,5 \\
3 & Kecepatan Arus & $\mathrm{m} / \mathrm{s}$ & 0,42 & 0,25 & 0,34 \\
4 & Oksigen Terlarut (DO) & $\mathrm{mg} / \mathrm{l}$ & 4,8 & 4,6 & 4,8 \\
5 & Derajat Keasaman $(\mathrm{pH})$ & & 6 & 6 & 6 \\
\hline
\end{tabular}

Tabel 3. Analisis Kelayakan Ekowisata Lubuk Larangan

\begin{tabular}{llll}
\hline No. & Unsur & Skor & Skor Maks \\
\hline 1. & Data Tarik & 1095 & 1260 \\
2. & Aksesibilitas & 537,5 & 600 \\
3. & Akomodasi & 45 & 180 \\
4. & Sarana dan Prasarana & 240 & 300 \\
\hline Jumlah & & 1917,5 & 2340 \\
\hline
\end{tabular}




\section{Sarana dan Prasarana}

Berdasarkan hasil penilaian, $87 \%$ responden menyatakan bahwa sarana penunjang lubuk larangan lengkap yang terdiri dari rumah makan, pusat perbelanjaan/ pasar , Bank, toko souvenir/ cenderamata dan angkutan umum. Sebanyak $13 \%$ responden menyatakan bahwa sarana penunjang yang tersedia hanya rumah makan, pusat perbelanjaan/ pasar, Bank dan angkutan umum (Gambar 4).

Untuk prasarana penunjang, 93\% responden menyatakan bahwa terdapat empat subunsur prasarana penunjang ekowisata yaitu kantor pos, rumah sakit/ puskesmas, jaringan listrik dan jaringan air minum, dan sebanyak $7 \%$ menyatakan bahwa yang hanya terdapat prasarana penunjang yang terdiri dari kantor pos, rumah sakit dan jaringan listrik. Berdasarkan penilaian tersebut, maka sarana dan prasarana penunjang memperoleh nilai skor 240 dari skor maksimum 300 .

\section{Analisis Kelayakan}

Hasil perhitungan kelayakan lubuk larangan sebagai ekowisata berbasiskan kearifan lokal masyarakat diperoleh nilai skor sebesar 1917,5 dimana dikategorikan sesuai bila dijadikan kawasan ekowisata lubuk larangan (Tabel 3).

\section{Karakteristik Pengunjung}

Pengunjung lubuk larangan umumnya berumur antara 17-25 tahun. Jumlah pengunjung laki-laki sebanyak 30 orang dan pengunjung perempuan sebanyak 25 orang. Pengunjung yang datang berasal dari berbagai daerah mulai dari sekitar Jorong Ikan Banyak (Lubuk Larangan) hingga daerah yang cukup jauh dari lubuk larangan yaitu Mungka, Lubuak Batingkok, Payakumbuh, Taeh Bukit dan Pekanbaru. Tingkat pendidikan terakhir sebagian besarnya adalah SMA dengan sebagai besar pekerjaan sebagai pelajar dan berstatus belum menikah sebanyak $54,5 \%$.

\section{Motif dan Aktivitas Pengunjung}

Sebagian besar pengunjung yang datang memperoleh informasi dari teman dan keluarga. Umumnya merupakan kunjungan pertama kali dan datang bersama teman dan keluarga. Sebagian besar pengunjung datang pada hari libur dan hanya menghabiskan waktu 1-3 jam dengan tujuan untuk menikmati keunikan dan menikmati keindahan alam dari lubuk larangan serta datang dengan menggunakan kendaraan pribadi. Kegiatan yang dilakukan adalah melihat/menikmati ikan yang ada pada lubuk larangan tersebut.

Persepsi pengunjung lubuk larangan sebagian besar menyatakan kegiatan memberi makan ikan dan berfoto merupakan objek unggulan yang bisa dilakukan di kawasan tersebut. Untuk mencapai kawasan sebagian besar pengunjung tidak mengalami hambatan. Kondisi sarana dan prasarana dinilai sudah baik dan untuk sistem pengelolaannya saat ini dinilai cukup baik. Seluruh pengunjung memberikan kesan menyenangkan untuk lubuk larangan Jorong Ikan Banyak dan ingin mengunjunginya kembali. Dari hasil kuesioner ini pengunjung menyatakan lubuk larangan Jorong Ikan Banyak layak untuk dijadikan suatu objek ekowisata dengan pengelolaan yang lebih terstruktur.

\section{Strategi Pengembangan \\ Identifikasi Faktor Strategis Internal \\ Kekuatan (Strengths)}

1. Tidak Adanya Eksploitasi Masyarakat Pada Kawasan Lubuk Larangan. Masyarakat disekitar lubuk larangan tidak melakukan eksploitasi terhadap sumberdaya alam yang ada di kawasan lubuk larangan.

2. Lubuk Larangan Sebagai Ekowisata. Kawasan lubuk larangan Jorong Ikan Banyak dengan keunikan dan keindahan yang khas menjadi daya tarik tersendiri untuk dijadikan sebagai salah satu tempat yang berpotensi mendatangkan pengunjung yang senang menikmati keindahan alam.

\section{Kelemahan (Weakness)}

Rendahnya Persepsi dan Partisipasi Masyarakat di Sekitar Lubuk Larangan. Pada kawasan lubuk larangan Jorong Ikan Banyak masyarakat sekitar kurang berpartisipasi dalam pengelolaannya dan hanya mengandalkan POKMASWAS (Kelompok Masyarakat Pengawas).

Kearifan Lokal Yang Mulai Ditinggalkan. Lubuk larangan Jorong Ikan Banyak merupakan salah satu bentuk kearifan lokal masyarakat yang memiliki peraturan dan sanksi. Saat ini ada sebagian 
masyarakat yang mulai meninggalkan kearifan lokal lubuk larangan, karena mereka tidak percaya dengan sanksi yang bersifat mistis. Aksesibilitas yang Relatif Jauh Dari Pusat Kota. Jalan menuju lubuk larangan ini telah terbuat dari aspal. Untuk kondisi jalan menuju kawasan tersebut dalam keadaan baik, namun jarak yang ditempuh pengunjung cukup jauh dari pusat kota.

\section{Peluang (Opportunity)}

Meningkatkan Kesejahteraan Masyarakat Lokal. Terwujudnya ekowisata lubuk larangan yang baik dan terstruktur akan memberikan peluang pekerjaan bagi masyarakat sekitar lubuk larangan. Terciptanya lapangan pekerjaan bagi masyarakat lokal akan mengurangi angka pengangguran.

Belum Ada Persaingan Yang Ketat. Kawasan lubuk larangan banyak terdapat di Kabupaten Lima Puluh Kota, namun tidak banyak yang dijadikan sebagai kawasan ekowisata. Lubuk larangan Jorong Ikan Banyak merupakan satu-satunya kawasan lubuk larangan yang terdapat di Kecamatan Gunuang Omeh dan telah dapat dikunjungi sebagai kawasan ekowisata. Hal ini menjadi peluang untuk menarik pengunjung karena belum adanya kawasan yang serupa dengan kawasan lubuk larangan tersebut. Lubuk Larangan Banyak Dikenal Masyarakat.

Kawasan lubuk larangan Jorong Ikan Banyak telah dikenal oleh masyarakat luas baik di sekitar Nagari Pandam Gadang maupun daerah lainnya. Informasi keberadaan kawasan tersebut memang hanya penyampaian dari mulut ke mulut, namun hal tersebut menimbulkan rasa penasaran akan kondisi dan suasana di kawasan tersebut. Meskipun promosi kawasan lubuk larangan ini masih kurang, namun tidak menjadi hambatan bagi pengunjung untuk mengetahui keberadaannya.

\section{Ancaman (Threat)}

Belum Ada Dukungan yang Pasti dari Pemerintah. Pemerintah Nagari Pandam Gadang telah merencanakan pengelolaan kawasan lubuk larangan menjadi suatu paket ekowisata dengan wisata rumah Tan Malaka dan bukit batu bulan. Namun belum terlaksana. Hal ini terkendalah oleh dana. Belum adanya kepastian kapan terlaksananya perencanaan tersebut menyebabkan kawasan lubuk larangan dinikmati dengan kondisi yang seadanya.

Pengunjung Sering Membuang Sampah Kedalam Sungai. Pengunjung dapat memberi makan ikan-ikan yang berada di kawasan lubuk larangan dengan makanan berupa pelet, kerupuk dan lainnya yang dibungkus dengan menggunakan plastik. Namun, pengunjung yang datang membuang sampah plastik dari bungkus makanan langsung ke sungai. Hal ini dikarekan kurangnya tempat sampah yang disediakan di sekitar kawasan dan juga kurangnya peringatan yang tegas dari pengelola kawasan sehingga pengunjung membuang sampah sembangan.

\section{KESIMPULAN}

Lubuk Larangan sudah ada sejak tahun 1822, pembentukannya melalui 3 tahapan: penyampaian ide/ gagasan, musyawarah dan pembukaan kawasan. Kawasan dikelola secara bersama oleh masyarakat melalui POKMASWAS. Terdapat peraturan dan sanksi yang mengikat pada kawasan Lubuk Larangan, diyakini dan dipatuhi oleh masyarakat setempat hingga sekarang.

Karakteristik fisika-kimia air Sungai Batang Sinamar mendukung tujuan wisata yaitu suhu berkisar 22,5-23 ${ }^{\circ} \mathrm{C}$, kedalaman perairan berkisar 71,75-120,25 cm, kecepatan arus berkisar 0,25-0,42 $\mathrm{m} / \mathrm{s}$, oksigen terlarut (DO) berkisar 4,6-4,8 mg/l dan $\mathrm{pH}$ 6. Kawasan Lubuk Larangan Jorong Ikan Banyak dinyatakan layak sebagai kawasan ekowisata dengan nilai skor total 1917,5.

\section{REKOMENDASI}

Untuk meningkatkan potensi lubuk larangan Jorong Ikan Banyak, diperlukan alternatif strategi pengelolaan yang tepat untuk pengembangan ekowisata lubuk larangan. Alternatif strategi pengelolaan tersebut terdiri dari tiga /prioritas yaitu: penataan wilayah dengan membentuk zonasi untuk kegiatan ekowisata dan kegiatan yang dilakukan masyarakat; ke dua, meningkatkan promosi; dan ke tiga penyusunan tata ruang ekowisata lubuk larangan Jorong Ikan Banyak dengan berbagai lembaga terkait dan masyarakat lokal. Selain itu, juga perlu adanya organisasi POKMAS sebagai pengelola kawasan lubuk larangan tersebut. Kemudian juga diperlukan penelitian lebih lanjut mengenai kualitas air dengan parameter yang lebih bagus. 


\section{UCAPAN TERIMA KASIH}

Terimakasih kepada Bapak Dr. Muhammad Fauzi, S.Pi., M.Si dan Bapak Dr. Ir. Adriman, M.si sebagai dosen pembimbing yang telah memberikan bimbingan, arahan dan motivasi dalam penyusunan jurnal ini. Terima kasih kepada semua pihak yang telah membantu dalam penyusunan jurnal ini.

\section{DAFTAR ACUAN}

Arafah, N. dan Flamin, A., 2012. Analisis Kelayakan Pengembangan Ekowisata Di kawasan Hutan Lindung Kecamatan Anggaberi Kabupaten Konawe Provinsi Sulawesi Tenggara. Fakultas Kehutanan Universitas Halu Oleo kendari. Kendari. Jurnal Layanan Kehutanan Masyarakat, Vol 1 No 12012.

Effendi, M. I., 2003. Telaah kualitas air bagi pengelolaan sumberdaya dan lingkungan perairan.Kanisius.Jogjakarta. 246 hal.

Firdaus, M dan Yesi, D. S. 2010. Pemanfaatan Dan Pengelolaan Kawasan Konservasi Sumber Daya Perikanan (Studi Kasus Di Lubuk Larangan Lubuk Panjang Barung-Barung Balantai, Kabupaten Pesisir Selatan, Sumatera Barat). J. Bijak dan Riset Sosek KP. Vol.5 No.1, 2010. 18 hal.

Lubis, Z.B. 2005. Menumbuhkan (Kembali) Kearifan Lokal dalam Pengelolaan Sumber daya Alam di Tapanuli Selatan. Jurnal Antropologi Indonesia Volume 29 (3): 239 - 254.

Maharani, I. 2016. Analisis Kelayakan Potensi Ekowisata Pada Kawasan Wisata Alam Bungi Kecamatan Kokalukuna Kota Baubau. Program Studi Manajemen Hutan Jurusan Kehutanan Fakultas Kehutanan Dan Ilmu Lingkungan Universitas Halu Oleo. 80 hal.

Oktaviani, O., Eko, P., Reny, P. 2016. Penguatan Kearifan Lokal Sebagai Landasan Pengelolaan Perikanan Perairan Umum Daratan Di Sumatera. J.Kebijak.Perikan.Ind. Vol.8 No.1 Mei 2016:1-12. 12 hal.

Peraturan Menteri Kelautan dan Perikanan Republik Indonesia. Nomor PER.30/MEN/2010. Tentang Pengelolaan Dan Zonasi Kawasan Konservasi Perairan. 14 hal.

Peraturan Nagari Pandam Gadang. Nomor 434 Tahun 2014 Tentang Pengelolaan Lubuk Larangan. 9 hal.

[PHKA] Perlindungan Hutan dan Konservasi Alam. 2003 (a). Pedoman Analisis Daerah Operasi Obyek dan Daya Tarik Wisata Alam (ADO-ODTWA). Direktorat Jenderal Perlindungan Hutan dan Konservasi Alam. Bogor.

Veraliza, Saam., Z, Thamrin. 2014. Manajemen Kearifan Lokal Lubuk Larangan Desa Pangkalan Indarung Kabupaten Kuantan Singingi Provinsi Riau. Jurnal Ilmu Lingkungan. ISSN 19785283. 2014:8 (2). 17 hal.

Yulianda, F. 2007. Ekowisata Bahari sebagai Alternatif Pemanfaatan Sumberdaya Pesisir Berbasis Konservasi. Bogor. MSP - FKIP IPB.

\section{Email :}

fionanovianti191@gmail.com

mfauzi.pku@gmail.com

adry04pku@yahoo.com 